DOI: $10.5007 / 2175-7976.2011 \mathrm{v} 18 \mathrm{n} 25 \mathrm{p} 142$

\title{
MEIO AMBIENTE E SAÚdE PÚBLICA: A URBANIZAÇÃO DE NOSSA SENHORA DO DESTERRO NO SÉCULO XIX
}

Susana Cesco*

Resumo: Nossa Senhora do Desterro, capital da Província de Santa Catarina passou por grandes modificações urbanas no século XIX. Até então era uma cidade periférica, apesar de ponto estratégico nas rotas de navegação do sul do Brasil. Em meados do século XIX ocorre um significativo crescimento urbano e comercial e, como conseqüência, um aumento nos problemas de saúde pública e abastecimento. Paralelo a esse processo de desenvolvimento do núcleo urbano de Desterro e do maior contato comercial com a capital do Império, novos usos começaram a ser atribuídos a locais como praias e rios e alguns costumes passaram por um processo de ressignificação. Isso gerou debates e questionamentos sobre práticas que até então eram comuns como o despejo de esgoto nas praias e a lavagem de roupas em rios e córregos da cidade. Esse texto é uma análise desse processo de transformação de práticas e costumes, um exame das novas percepções locais acerca das idéias de higiene e convívio social.

Palavras-chave: Urbanização. Doenças. Higiene. Salubridade.

\begin{abstract}
Nossa Senhora do Desterro, capital of the Province of Santa Catarina went through major urban changes in $19^{\text {th }}$ century. Until then it was a peripheral city, despite a strategic shipping routes in the south of Brazil. In middle of $19^{\text {th }}$ century a significant urban and commercial growth occurs, and as consequence, an increase in the problems of public health and supplying. Parallel to this process of development of the urban center of Desterro and the biggest commercial contact with the capital of the Empire, new uses had started to be attributed to the beaches and rivers and some customs had undergone a redefinition process. This has generated debates and questions about practices that until then were common as the sewage disposal on beaches and the laundering clothes in rivers and streams of the city. This text is an analysis of this process of transformation of practices and customs, an examination of the new local perceptions about the ideas of hygiene and social life.
\end{abstract}

Keywords: Urbanization. Illnesses. Hygiene. Salubrity.

* Bolsista PRODOC/CAPES no CPDA/Universidade Federal Rural do Rio de Janeiro - UFRRJ.

E-mail: susanacesco@yahoo.com.br 
Meio ambiente e saúde pública: a urbanização de Nossa Senhora do Desterro no século XIX

\section{DO GLOBAL AO LOCAL: QUESTÕES DE SALUBRIDADE NO BRASIL E NA ILHA DE SANTA CATARINA}

O presente trabalho originou-se de um projeto mais amplo, que pretendia analisar as transformações ambientais na Ilha de Santa Catarina - localizada no litoral sul do Brasil - durante o século XIX. O resultado final da pesquisa abordou essa temática sob três aspectos: floresta, agricultura, e área urbana em transformação, relacionadas com as percepções da sociedade local. Nesse sentido, a Ilha de Santa Catarina, com seu espaço restrito e limites 'naturais' impostos pela insularidade, possibilitou uma análise mais clara de pontos que em outros lugares ficariam mais dispersos ou diluídos e, talvez de forma ainda mais contundente, o entrelaçamento de questões que normalmente são tratadas de forma isolada pela história. Por conta disso, a proposta de uma análise interligada da história e do meio ambiente da Ilha de Santa Catarina no século XIX permitiu uma percepção mais ampla das 'causas e efeitos' de algumas mudanças sociais e naturais locais. Para esse texto específico deter-me-ei ao aspecto urbano da Ilha, a cidade de Nossa Senhora do Desterro, então capital da Província de Santa Catarina, no período em questão.

A Ilha de Santa Catarina durante o século XIX deixou de ser o pequeno povoado, colonizado por açorianos e madeirenses, que iniciou o século cercado de matas e com algumas roças para a produção de bens de primeira necessidade. Esse processo de transformação ambiental e social foi percebido pela derrubada das matas, pelo surgimento de novas freguesias no interior da Ilha e também pelo crescimento da cidade de Nossa Senhora do Desterro.

Também é nesse período, final do século XVIII e XIX que ideias ligadas à geografia, espaço e território passam a ser relacionadas com salubridade, direcionando muitas decisões sobre fundação de vilas e povoados. Nessa época de expansão colonialista, em que novas doenças eram identificadas à medida que lugares com diferentes climas, solos, relevos, paisagens botânicas e hidrografias eram ocupados, teorias e pesquisas de médicos e higienistas eram associadas ao discurso do determinismo geográfico.

Tais ideias de salubridade e espaço geográfico estão ligadas a uma corrente higienista - um segmento da medicina européia - que prestou especial atenção ao meio natural e sua possível relação com os problemas patológicos. A teoria de Hipócrates, inaugurada com o livro Dos ares, das águas e dos lugares, sobre a relação das questões ambientais com a saúde pública foi revisitada e serviu como uma base que justificou e orientou os primeiros trabalhos que influenciaram diversos projetos urbanísticos. Foram esses estudos os responsáveis por muitas das mudanças, tanto na estrutura física dos espaços urbanos como nas habitações e nos costumes dos indivíduos no decorrer do século XIX. ${ }^{1}$ Também é decorrente dessa teoria a valorização do 
consumo de água pura para ingestão e para banhos, o que originou os sistemas de abastecimento por meio de aquedutos e o valor terapêutico dos banhos de mar. De acordo com Vigarello, a maior parte das topografias médicas do final do século XVIII em diante associa saúde à mobilização da água, escorrendo pelas cidades, por valas e canais e limpando-a, bem como promovendo a correção do ar. $^{2}$ A palavra higiene passa a ocupar espaço nos manuais de saúde nessa mesma época. Higiene torna-se um ramo específico do saber médico e qualifica não mais "saúde (hygeinos significa em grego o que é são), mas o conjunto dos dispositivos e dos saberes que favorecem a sua conservação." $\mathrm{A}$ mudança de status da medicina no que tange a higiene, pode ser percebida pelo aparecimento de novas instituições como as comissões de salubridade, criadas no Brasil durante o período Imperial e encarregadas de inspecionar localmente manufaturas, oficinas, estabelecimentos produtores de miasmas diversos.

Se considerarmos que as cidades brasileiras tiveram muitos elementos de sua construção inspirados em cidades européias, ou ao menos idealizados dessa forma (praças, prédios públicos, igrejas, entre outros) entende-se a preocupação médica existente, fato comum na Europa nesse período. Um dos principais focos da atenção de políticos e urbanistas no Brasil do século XIX estava voltado a uma 'adaptação' do meio ambiente para uma melhor adaptação social dos habitantes, muitos vindos da própria Europa.

No Brasil, o surgimento da ideologia da higiene inicia na então capital do Império, a cidade do Rio de Janeiro e espalha-se, fazendo com que essas preocupações médicas e saneadoras chegassem a Nossa Senhora do Desterro. Considerando o desenho urbano e sua dinâmica de crescimento, os pontos críticos no que se refere à habitação dos pobres e focos de doenças eram muito próximos ao centro da cidade e, conseqüentemente, da habitação dos mais ricos. A identificação desse problema já vinha do início do século XIX e foi motivadora das primeiras leis municipais sobre o tema salubridade, mesmo que a ideia de salubridade não fosse a mais apropriada de acordo com os preceitos higienistas atuais. Prova disso é que, em 1830 a Câmara Municipal aprovou a lei que determinava que o lixo urbano fosse depositado na praia, nos rios e no mar junto com os esgotos, para evitar que os detritos se acumulassem nas ruas. Leis semelhantes destinadas a resolver o mesmo problema também foram promulgadas no Recife e no Rio de Janeiro, onde o destino das águas servidas era assunto espinhoso e de difícil solução. A questão, que afetava a todos, era tratada de maneira semelhante em todas as casas. As fezes e dejetos eram acumulados em barris em algum canto das casas e, quando estavam cheios, eram recolhidos por escravos que os transportavam e os despejavam no mar ou em rios e pântanos no entorno da cidade. Era na cabeça que os escravos conduziam essa mal cheirosa carga e, segundo Manuela Arruda dos Santos, 
esses barris eram chamados de 'tigres' e os seus condutores, de 'tigreiros'. Talvez o nome fosse uma alusão à coragem dos carregadores ou, quem sabe, à imagem desagradável das barricas que, ao transbordar, espalhavam fezes nos corpos dos escravos e dos negros de ganho, numa combinação que lembrava a pelagem dos tigres. Existem versões que afirmam que o apelido foi dado porque, ao avistar os negros levando barris de dejetos, os transeuntes, com medo de ficarem sujos, afastavam-se rapidamente, como se fugissem de um animal selvagem. ${ }^{4}$

Essas figuras tentaram ser controladas por uma legislação sem muito efeito por longos anos. Horários e locais de despejo eram recomendados, lançamentos desses materiais pelas janelas dos sobrados eram proibidos, porém, apenas em 1877 houve o primeiro pedido de concessão para um serviço de remoção de lixo, águas servidas e matérias fecais em Desterro. A atividade seria desempenhada por particulares e paga pela Câmara Municipal que não tinha funcionários para tal função. O serviço, que seria desempenhado quase que totalmente por escravos que recolheriam em carroças os ditos dejetos, conduzindo-os a locais mais distantes do centro da cidade, pouparia, se não as narinas, ao menos os olhos dos transeuntes desse desagradável transporte. Nesse período, algumas novas casas já tinham em seu espaço construído uma latrina, sendo que essa poderia ser edificada em qualquer ponto do terreno, desde que não promovesse prejuízo aos vizinhos com mau cheiro ou despejos. ${ }^{5}$

O problema dos dejetos urbanos estendeu-se por todo o século XIX. Em Desterro mesmo essa tentativa de melhoria com o transporte e carroças demorou a se efetivar e, somente em 1884, o primeiro serviço de coleta de lixo e matérias fecais, através de direito concedido a coletores particulares, aconteceu. $\mathrm{O}$ destino desses materiais continuava sendo o mar. Somente muito mais tarde, já em princípios do século XX, em 1910, sob governo republicano, é dada concessão para implantação de uma rede de esgotos na Capital de Santa Catarina. ${ }^{6}$

\section{O DESENHO URBANO}

A Ilha de Santa Catarina possui uma forma alongada que acompanha o litoral. Com comprimento médio de $54 \mathrm{~km}$ e largura de $18 \mathrm{~km}$, seu litoral é bastante recortado e seu relevo montanhoso e descontínuo. Nossa Senhora do Desterro segue, em linhas gerais, o desenho das cidades e vilas portuguesas que foram instaladas no Brasil desde o século XVI. Uma praça central de onde saiam ruas que formavam quadras regulares, alteradas apenas por acidentes 
geográficos que não pudessem ser adaptados. De acordo com o último relatório sobre o tema feito no século XVIII, em 1796, a população aproximada era de 10.036 pessoas, dessas, 3.759 residiam na Vila e Capital de Nossa Senhora do Desterro; 1.040 na Freguesia do Ribeirão; 1.916 na Freguesia da Lagoa; 2.447 na Freguesia das Necessidades e os restantes eram soldados do Regimento da Ilha. Desse total, 2.017 eram escravos pardos e pretos.

O crescimento a partir de quadras demarcadas, tendo como centro a praça e a catedral só sofreu interrupção quando se deparava com as chácaras maiores, situadas em localidades como Trindade e Saco dos Limões. ${ }^{7}$ A área urbana, representada pelo mapa abaixo, correspondia à porção do território que devia uma taxa equivalente ao percentual de $10 \%$ sobre todas as formas de rendimento dos súditos reais, chamada 'Décima Urbana'.

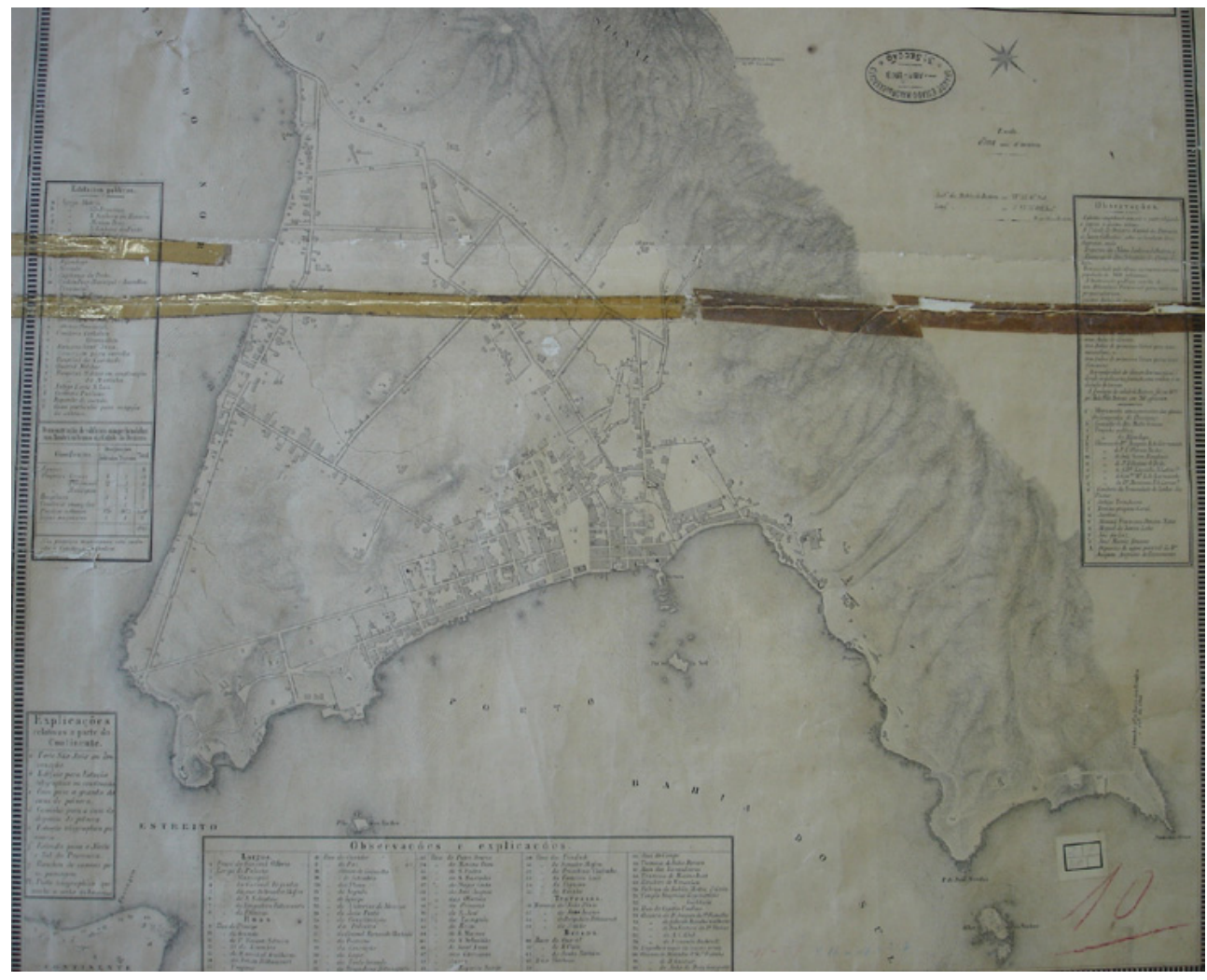

Planta Topographica da Cidade do Desterro Levantada por Ordem e na Presidência da Província de Santa Catharina do Ilmo. Exmo. Snr. Dor. Alfredo D'Escragnolle Taunay pelos Engenheiros Major Dor. Antonio Florêncio Pereira do Lago e Carlos Othom Sehleppal. Anno de 1876 (08.01.1686 Acervo: Arquivo Histórico do Exército). Observação: A planta compreende somente a parte edificada e sujeita à décima urbana. 
Em Desterro, especialmente na primeira metade do século XIX, as praias ainda eram locais exclusivos de despejos, o que não era visto como um problema por autoridades e moradores, desde que fossem seguidas algumas regras, uma vez que a praia até então não havia sido associada à saúde, era sim um ponto limiar entre terra e mar, uma fronteira entre o habitável e o desconhecido, pendendo mais para este. Prova disso é o Código de Posturas Municipal que, ainda em 1830 cuida de promulgar leis sobre o modo de dispor das 'imundícies', indicando que “as águas sujas que pudessem exhalar miasmas pútridos e infectar o ar não fossem lançados à rua, mas, juntamente com os detritos dos cortumes, para não infectar a atmosfera, jogados no mar" ${ }^{8}$ Muito lentamente essas práticas vão se alterando. Em fala de 1849, o então presidente da Província, Severo Amorim do Valle, justifica a necessidade imediata de transferir a

\begin{abstract}
sujíssima cadeia que ficava nos térreos da Câmara, da praça que ostentava as mais importantes edificações da cidade, sendo rodeada das mais belas propriedades [e que] dela saem diariamente despejos que são lançados na mesma praia que faz frente esse edifício [o novo Mercado] e onde aporta o peixe, a carne e todos os generos comestíveis. ${ }^{9}$
\end{abstract}

Aliado a isso, o código de posturas de 1845 já indicava algumas proibições e multas relacionadas à higiene. Como o artigo 15 , capítulo $2^{\circ}$ que estipulava multa de $4 \$$ réis para os que prejudicarem, de qualquer forma, as fontes públicas. Em caso de reincidência a multa seria dobrada. Outro artigo com termos semelhantes era o número 20 , capítulo $2^{\circ}$, que proibia qualquer curtume nos limites da cidade. ${ }^{10}$

Mais tarde, em 1864, João Ribeiro de Almeida, Primeiro Cirurgião da Armada, em seu Ensaio sobre a salubridade, estatística e pathologia da ilha de Santa Catarina, já associava, diretamente, questões de saúde ou doença com saneamento e higiene. Um dos pontos mais debatidos pelo autor é a associação da água poluída de riachos e fontes com as doenças da população. ${ }^{11}$ Nos anos seguintes novas regras surgiram para 'controlar' a insalubridade de Desterro e algumas delas vem no Código de Posturas municipal de 1888. Em seu artigo 54, capítulo $2^{\circ}$, "permitia lançar a praia [o lixo] a qualquer hora; as águas servidas e as fezes, só a noite, das 10 horas até o alvorecer, as 5". ${ }^{12}$ Essas medidas tinham função muito mais de poupar os olhos que, propriamente, amenizar ou resolver o problema da poluição. Quando se restringia aos horários noturnos, o despejo de matérias fecais preservava as pessoas ricas de ver o fato ocorrendo e não as praias e o mar desses dejetos. Outro ponto importante diz respeito ao cheiro, 
pois se acreditava muito mais em contaminação por odores que por contato, os tão propagados miasmas.

A segunda metade do século XIX é um período em que novas teorias sobre contaminação e doenças começam a consolidar-se. Os miasmas ainda são temidos, mas surgem também as preocupações com a contaminação pelo contato físico. Desterro foi profícua em críticas sobre o saneamento básico e os problemas de um processo de urbanização sem controle ou sem preocupação com a natureza. O jornal $O$ Argos em matéria de 09 de janeiro de 1862 faz uma crítica veemente às autoridades desterrenses sobre o estado da praia do Mercado; lamentando-se por saber que está a 'clamar no deserto', o jornal questiona a Polícia Municipal na pessoa do Fiscal da Capital sobre o porquê de não tomar providências no caso da citada praia, onde o público transita desde o romper do dia até quase o escurecer com abundância de matérias fecais misturadas à areia; as exalações fétidas que ali se respiram são excessivamente incômodas. ${ }^{13}$ Até que ponto as críticas do jornal eram dirigidas ao problema da poluição ou, ao contrário, à pessoa do Fiscal da Capital não podemos saber, mas o fato de uma questão sócio-ambiental, ligada ao saneamento básico, ser tema de reportagens é significativo para percebermos as mudanças de percepção que vinham ocorrendo, ao menos em alguns segmentos da sociedade.

Essas novas preocupações locais aparecem claramente no texto de João Ribeiro de Almeida, citado anteriormente. Atribuindo às 'condições naturais' de uma ilha muitos dos problemas de insalubridade, o autor reconhece certo grau de verdade nas palavras um tanto quanto exageradas do então presidente da Província, Dr. João José Coutinho, quando, em sua fala de 1854, dizia que "a cidade de Desterro é inteiramente imprópria para habitação humana". ${ }^{14}$ Porém, diferente da maioria dos autores desse período, João Ribeiro de Almeida contraria a idéia de que os miasmas são os responsáveis maiores pelas doenças. Usando como base os obituários de 01 de julho de 1862 até 30 de junho de 1863 e uma lista de doenças que causaram mortes nesse ano, elaborou uma ligação entre a sujeira espalhada pela cidade, resultado do hábito comum de ver a rua como ponto de descarte do que não tem mais uso - de móveis velhos a restos de comida e águas sujas - com as doenças.

Segundo o autor, o contágio se dava pelo contato desses dejetos com a água usada para beber, cozinhar, lavar roupas e limpar as casas, do próprio contato das pessoas com a sujeira, aliada a maus hábitos de higiene pessoal, muito mais que pelo mau cheiro da cidade, que já nem era percebido pela população, tão acostumada esta estava. Somando-se a isso, questionava-se a quantidade e a qualidade dos alimentos consumidos em Desterro era suficiente e apropriada, além de um levantamento do consumo de pão e carne - únicos possíveis de serem controlados devido aos registros de entrada e saída do Mercado Público e do abatedouro municipal - e uma crítica à impossibilidade de 
saber da circulação de outros bens de consumo locais em virtude da fiscalização efêmera sobre as carroças e canoas que rodavam entre a cidade e o campo e entre os portos próximos.

O texto não descarta algumas pré-condições geográficas e climáticas como sendo um 'estímulo' à proliferação de alguns males. $\mathrm{O}$ fato de se tratar de uma ilha traz consigo o que o autor chama de "qualidade da athmosfera marítima". ${ }^{15}$ De acordo com Ribeiro de Almeida,
é devido em grande parte, a isso, que a humidade é tão considerável na Ilha e particularmente na cidade de Desterro, a ponto de impregnar tudo, objetos inanimados ou seres vivos, em lugar recluso ou ao ar livre. Semelhante estado hygrometrico não pode deixar de contribuir poderosamente para a produção de moléstias. ${ }^{16}$

Além da 'atmosfera', os solos da Ilha, por sua propriedade "argilosa e por uma camada pouco considerável de terra vegetal; o sub-solo é sempre granítico [...] devendo-se assim prestar-se bem mal a infiltração das águas, as quaes por isso mesmo estagnarão" ${ }^{17}$ Outra conseqüência dos malefícios causados pela água estagnada está no artigo 16 , capítulo $2^{\circ}$, do Código de Postura da Câmara Municipal de Desterro ainda em 1845, que "determina aos proprietários o prompto dessecamento dos pântanos, que existião em seus terrenos", ${ }^{18}$ do contrário poderiam ocorrer também acidentes com animais como os já registrados entre a rua do Passeio e a do Matto Grosso onde existia um imenso pântano.

Essa instrução aos proprietários também foi adotada, gradativamente, pelas autoridades locais no que se refere aos mangues e charcos da cidade. A facilidade da extração de madeiras desses locais pela proximidade do centro urbano e o transporte para os curtumes e engenhos da área, contribuíram par a expansão da cidade - caso da região da Praia de Fora e da Praia do Menino Deus, respectivamente ao norte e ao sul da cidade, originalmente locais pantanosos. No caso dos aterros, tão comuns em áreas urbanas litorâneas como o Rio de Janeiro, Desterro tem seu primeiro projeto registrado em mapas do Exército em 1846 e referia-se a área que ia da praça central rumo ao sul, até a altura da praia do menino Deus. Isso já demonstrava, apesar de o plano não ter se concretizado até a última década do século, a 'necessidade' de expansão urbana.

É nesse momento que percebemos mais claramente a redefinições nos atributos de lugares públicos e nos 'usos' atribuídos ao mar e às praias da Ilha de Santa Catarina. A emergência imposta pelos despejos crescentes, o mau cheiro, as valas nas ruas forçaram uma nova atitude por parte dos habitantes locais. Somado a isso, o crescimento urbano propriamente dito limitava o 
acesso 'à natureza', deixava os moradores da cidade enclausurados, com suas casas voltadas unicamente para a rua. As praias passaram a figurar como locais de passeio e reabilitação, refúgio da vida na cidade, ar puro, desde que devidamente saneadas e tratadas.

\section{O MAPEAMENTO DA INSALUBRIDADE EM DESTERRO}

Em Desterro, a água usada pela população provinha de três fontes: Fonte do Campo do Manejo, Fonte da Carioca e Fonte da Palhoça. A água utilizada para beber, cozinhar, limpeza de casas e corpos vinha dessas fontes. Muitas das doenças contraídas pelos moradores da Ilha também provinham delas. A poluição das águas era uma realidade, apesar de algumas tentativas legais de prevenção como o artigo 86 do Código de Posturas Municipal de 1845, em que eram proibidos banhos nas praias e nas fontes, sob pena de multa aos livres e encarceramento aos escravos que assim o fizessem. As três fontes que abasteciam a cidade eram formadas por olhos d'água que davam origem a rios e córregos da Vila, como o Riacho da Pedreira e o Rio da Fonte Grande. Eram os primeiros pontos de coleta de água que, seguindo seu curso, era usada para lavagem de roupas, construção de chafarizes, limpeza das casas, o trato dos animais e demais necessidades da população.

Em artigo do jornal $O$ Conciliador Catarinense de 17 de novembro de 1849, é transcrito o relatório apresentado ao Presidente da Província pelo Capitão de engenheiros João de Souza Mello e Alvin sobre as fontes públicas de Desterro. Mello e Alvin, encarregado de executar um processo de nivelamento e ordenação dos cursos e olhos d'água que abasteciam as fontes, fez uma descrição do estado em que elas se encontravam e realizou testes de pureza de água. Os testes eram três: prova de dissolução de sabão, cozimento de legumes em tempo considerado hábil e chapa de cobre em que se analisavam as manchas produzidas por pingos de água das fontes.

A situação de cada fonte descrita por Mello Alvin era a seguinte:

[...] Fonte do Campo do Manejo: esta fonte, que foi construída pelo engenheiro civil Carpineti no anno de 1844, he provida por três veios d'água que correm doze palmos pouco mais ou menos abaixo, do nível do [mutilado] tendo origem no sobredito morro do signal. A agoa he tirada por meio de uma bomba de roda, que exige não pequeno esforço; na atualidade, porém, creio que por falta de torneiras, ou por outro qualquer desconcerto, ninguém se serve dela. [...] Fonte da Carioca: Foi edificada essa pelo referido Carpineti no anno de 1842, em uma baixada nos fundos da cidade, e he alimentada por uma grande porção de olhos d'agoa que estão 
pouco abaixo da superfície do terreno. A fonte está situada a 6 braças ao norte da Rua da Carioca, que he a ultima que corre na direção paralela a da praia que lhe fica ao sul. A sua arquitetura he muito semelhante a do campo do manejo, e assim também as dimensões, e como naquela, há um pantano que a cerca e um riacho que a atravessa [...] Ainda como na outra quem faz subir a agoa he uma bomba de roda, cuja manivela esta da parte de fora entre duas torneiras, que, tendo desaparecido, a actual Câmara mandou substituir por duas calhas de madeira que igualmente já não existem. [...] a operação da chapa de cobre foi favorável a pureza da agoa porquanto as gotas nella derramadas deixaram leves indícios da sua existência. [...] Fonte da Palhoça: Por detrás do bairro da Figueira, no lugar chamado - Palhoça - foi construída essa fonte no anno de 1831, pelo cidadão Floriano José Vilella. Está situada 40 braças ao Norte da Rua do Senado, e consta de duas peças. Depósito d'agoa e caixa de distribuição. [obras mal feitas segundo Mello Alvim][...] Pela experiência que procedi tanto na agoa da caixa como na do deposito, que he de nascente, conclui como sendo a agoa desta e daquella, péssima [...]. ${ }^{19}$

A conclusão do dito engenheiro foi de que "as agoas das três fontes publicas de que se servem os habitantes desta capital, não são rigorosamente potáveis; e faltando-lhe essa qualidade essencial, fácil hé reconhecer, o quanto devem ser prejudiciais a saúde". ${ }^{20}$

A questão da água é longamente discutida também por Ribeiro de Almeida. Um dos tópicos que mais merecem destaque é o referente aos três rios do centro da cidade, dois deságuam na Praia de Fora, na Baía Norte e um deságua na praia do 'Menino Deos', na Baía Sul. Este, chamado Fonte Grande, em todo o seu curso serve de lavadouro publico. Tal fato é o causador de boa parte da poluição do riacho e dos miasmas e doenças relacionadas à água contaminada na cidade de Desterro. Para usar as águas do riacho em suas lavagens de roupas,

se torna preciso represar suas águas minguadas [...] fazendo-se um sem número de pequenos charcos, em cuja superfície existe uma crosta (com reflexos metálicos as vezes) proveniente da enorme quantidade de materiais de toda a espécie, resultante da lavagem e dos despejos que se fazem nas margens ou no próprio riacho. Essas matérias ficão em suspensão ou em dissolução, o que torna as águas escuras e asquerosas. ${ }^{21}$ 
Essas represas feitas pelas lavadeiras eram rompidas e as águas se renovavam apenas em dias de enxurradas, 'quando o mar remonta o curso do riacho' da Pedreira, o que, segundo o autor, era tão ruim quanto à estagnação, haja vista a crença corrente de que a mistura de água doce e salgada não era bom ou higiênico. Esse mesmo riacho foi canalizado em seu trecho final pouco antes da ponte do Vinagre, para

evitar inundações quando ele se assoberba com as chuvas; são essas águas negras, lodosos e nauseabundas [...] vem desaguar na praia do Menino Deos, praia que na vazante fica descoberta em grande extensão, apresentando um fundo lodoso e infecto [...] [provocando] decomposição dos sulfatos alcalinos da água do mar existente no lodo pelas matérias orgânicas e formação do acido hydro-sulfurico, bem caracterizado por seu fétido particular. ${ }^{22}$

Essa realidade de rios urbanos responsáveis pelo abastecimento da cidade era grave em Desterro, pois toda a porção central a oeste da Ilha, ponto onde se fundou a vila, era banhada por rios de pequena vazão, dificultando a renovação das águas - exceto em dias de chuvas fortes. Existiam outros rios e a Lagoa do Peri que apesar de serem importantes fontes de água doce estavam localizadas em pontos mais afastados da Ilha e nunca foram usados para suprir a escassez em função da ausência de obras de canalização para tal. Em Desterro no século XIX usava-se apenas a água que estava próxima, se doce para beber ou lavar roupas - águas provenientes dos rios e córregos, - se salgada para despejo de materiais inservíveis - água do mar.

Os problemas de saneamento e falta de condições para a habitação são reforçados ao se constatar de onde vinha a água para o abastecimento da cidade. Os três chafarizes públicos eram vistos como depósitos de água estagnada e, conseqüentemente, focos de muitas enfermidades. Para piorar a situação, já em 1860 , se indicava o perigo de falta de água até para abastecer os chafarizes já existentes e novas ideias de melhorias foram lançadas nos anos posteriores, ao menos no campo teórico. Naquele ano, a Câmara solicitou a tomada de medidas

para diminuir o desmatamento do morro que envolve a cidade, pois ele seria a causa da crescente escassez de água que afligia a população. Foi nesse mesmo ano que o comércio de água se iniciou em Desterro. O líquido era recolhido bem cedinho, em fontes particulares. Era coletado por uma ou duas pessoas sem que o fundo da fonte fosse muito revolvido e os sedimentos contidos no fundo sujassem a água. Somente em 1880 é que se falou pela primeira vez 
em canalizar a distribuição de água. Entretanto, a proposta de encanamento não foi levada adiante e, em 1887 ainda se vendia água pelas ruas. ${ }^{23}$

Não só a falta de água causava preocupações, mas também sua drenagem quando as chuvas caiam com mais força pela cidade. Charcos podiam ser vistos nas ruas de Desterro, pessimamente empedradas e que serviam como embaraço para curso das águas pluviais. Até meados do século XIX, poucas ruas eram calçadas como o Beco do Quartel, A Ponte do Vinagre e a Rua Áurea. A situação era ainda pior em três bairros da cidade a Toca, a Pedreira e a Figueira, locais onde eram encontradas casas que, segundo Almeida, "eram inferiores as senzalas dos pretos de certas fazendas". ${ }^{24}$ Esses bairros estavam localizados na parte sul, norte e leste de Desterro, ou seja, o centro da cidade era cercado por pontos críticos no que se refere a focos de doença e problemas sociais, uma vez que seus moradores eram desempregados ou subempregados, escravos de ganho, negros forros e toda sorte de pessoas pobres.

O caso do bairro da Pedreira era ainda mais preocupante, segundo o mesmo autor. Era cortado pelo arroio da Fonte-grande e atingia o ápice da sujeira a partir da Rua do Vigário até o mar.

O que ahi se vê é realmente inaudito; por toda a parte montes de lixo já estratificado; lagos de ourina podre em alguns pontos (na beira de um riacho!); aqui e ali cadáveres dispersos de cães, gatos, ratos, galinhas e em períodos mais ou menos avançados de putrefação; restos de tudo, objetos putrescíveis ou não, tudo ahi se encontra $[\ldots] .{ }^{25}$

Outro bairro citado por esse autor como sendo crítico em termos de higiene é a Figueira, que além de ser passagem das águas que vem da fonte da Palhoça é o ponto de "habitação de grande parte das meretrizes da mais baixa classe" 26 de Desterro, fazendo do riacho depositário de todas as imundices provenientes dessa vizinhança. Conseqüência dessas práticas de higiene pública eram as epidemias e moléstias que se registravam na população local. Apenas no ano de estudo dos obituários citados pelo autor, verificaram-se mortes por anemia, tétano, asma, tuberculose, sífilis, varíola, gripe, coqueluche, meningite cérebro-espinhal e disenteria, esta última já havia sido a causadora de uma onda de mortes há alguns anos em Desterro. E todas essas doenças tinham relação direta ou indireta com a salubridade dos locais de moradia dessa população.

Que a situação, em meados do século XIX, era, no mínimo, instável quanto à saúde pública, especialmente quanto às epidemias, era claro para o autor como para jornalistas e viajantes estrangeiros, porém, o que se questionava 
era o descaso e, muitas vezes, desleixo por parte da administração da cidade. Exemplo disso são os questionamentos do mesmo Ribeiro de Almeida sobre a inexistência de uma alameda de árvores sequer, em toda a cidade de Desterro. O fato de ser uma prática de baixo custo e manutenção apenas deixa o autor mais indignado, uma vez que tal prática seria de baixo custo e conservação. Para corroborar essa afirmação, o autor se remete à Mr. Chevreud, cuja tese é de que "as plantações [...] constituem um meio de tornar salubre e purificar o solo, pois que as árvores não podem crescer sem que neles sorvão os materiais alteráveis, causa próxima ou remota da infecção". ${ }^{27}$ Essa observação do autor já é uma referência aos passeios públicos e jardinas botânicos existentes em muitas cidades européias e também no Rio de Janeiro, que seriam uma espécie de 'pulmão' para tais cidades já devastadas e urbanizadas ao extremo e que só perceberam a necessidade de algum contato com a natureza em sua 'forma mais primitiva' quando já a tinham destruído, tendo que se valer de meios artificiais para obtê-la.

\section{ESPAÇO E SOCIABILIDADE}

Esse novo caráter de saúde e lazer que, gradativamente, atribuiu-se a praias e praças seguia o exemplo do que já vinha ocorrendo na Europa, vagarosamente desde o início do século XVIII. Uma grande mudança após um longo período de medos e precauções relacionados à água que surgiram ainda no século XVI, quando a peste assolou o continente e costumes como o dos banhos públicos foram suprimidos. Com o crescimento urbano e o 'enclausuramento' das cidades, as casas voltavam-se para a rua, criando muros imaginários ou não, que as isolavam das áreas ainda 'não dominadas' da natureza. Porém, isso despertou nessas populações urbanas a busca por refúgios bucólicos, afastados dos odores e da 'opressão' da cidade. As praias e outros tantos pontos tidos como naturais tornaram-se, gradativamente, refúgios da nova vida urbana, além de prováveis fontes de cura.

As mudanças foram impulsionadas por jornais, Posturas Municipais, leis e decretos que, além de agirem como mecanismos de controle e definição do que se podia ou não fazer em determinados locais, faziam circular as ideias de 'espaços públicos ao ar livre'. Para tanto, entende-se que houve um processo de redefinição de usos de locais como praças, ruas e praias. Freqüentar a praça em horas tardias, circular pelas ruas sem destino definido e ir às praias não eram hábitos das pessoas ricas ou senhoras de família; mais do que isso, não era um hábito 'nobre', como conseqüência, ao menos em parte, as ruas eram precárias para os pedestres, a praça mal cuidada e escura e as praias locais de despejos. Segundo Maria Alexandre Louzada, é importante considerar que "não se está perante qualidades intrínsecas do espaço, pois que essas qualidades 
são o resultado de construções sociais e o produto de usos sociais". ${ }^{28}$ A idéia de socialização desses espaços públicos estimulou algumas medidas tomadas em Desterro, especialmente após a metade do século XIX, no que concerne a infra-estrutura e dinamização dos possíveis locais de encontro de "pessoas de bem' que viviam em uma cidade em crescimento e em contato com as novidades do mundo.

Sennet considera que a palavra 'público' adquiriu o seu significado moderno no século XVIII: "a vida pública passou a designar a vida social passada fora da família e dos amigos chegados, o domínio público de contato entre conhecidos e estranhos". ${ }^{29}$ Isso foi muito influenciado por novos códigos de civilidade e pelo impacto de instituições como a polícia e a Igreja. ${ }^{30}$ Essa afirmação de novas regras de comportamento foi moldada no Brasil no século XIX para a vinda da família real com o crescimento urbano em torno da corte. A nova regra de civilidade da sociedade patriarcal foi transferir o engenho para a cidade na forma de sobrados suntuosos de frente para a rua. As regras do convívio elegante passaram a incluir idas ao teatro, caminhadas nos novos passeios públicos - inclusive das mulheres - ou tomar a fresca na praia em horários apropriados em que o sol não castigasse.

As praias que até então recebiam os despejos de lixo e águas sujas, além dos corpos de animais, passam a figurar como locais de passeio e reabilitação. O crescimento da cidade levou muito em conta a 'dominação' da natureza selvagem com a contenção de miasmas, o aplainamento de morros, a drenagem de charcos, a canalização de rios e a limpeza das praias. Os ambientes suburbanos, como sítios e chácaras, já eram usados largamente como refúgios para a pressão das grandes cidades na Europa e, no caso do Brasil, isso também já ocorria no Rio de Janeiro. A praia veio somar-se a esses locais e passa a ser também em Desterro, em fins do século XIX, como nessas outras cidades, um local de contato com a natureza em estado mais puro. Pode-se comprovar isso com o surgimento das casas de praia ou, na própria cidade, das casas com a frente voltada para o mar. Essas casas com caráter predominantemente urbano localizavam-se especialmente na Praia de Fora, local distante do centro de Desterro, ligado a esse pela Rua Esteves Júnior. Essa praia era ponto de encontro de famílias que, além de uma casa no centro da cidade, possuíam propriedades na área. As residências voltadas para o mar eram frequentadas, principalmente, no verão.

A iluminação da praça central, atual Praça XV de Novembro, e de ruas adjacentes por lampiões, também na segunda metade do século XIX, foi outra medida tomada com o intuito de melhorar locais da cidade, numa tentativa de ressignificar espaços. Tal medida foi defendida na Câmara e em alguns veículos de imprensa como necessária para a melhor circulação de pessoas e mercadorias e possíveis contatos e conversas entre elas, não necessitando para 
isso esperar pelas noites de lua cheia. Aliás, a questão da iluminação pública foi largamente discutida pela Imprensa, especialmente no que se refere ao cumprimento ou não dos contratos de arrendamento. Esses contratos eram oferecidos em editais públicos e arrematados geralmente por comerciantes locais que usavam escravos para executar os serviços e os mantinham com verbas que a Câmara destinava para esse fim. Geralmente, os arrematantes reclamavam das baixas verbas destinadas aos serviços. Em 1853, a iluminação pública de Desterro ficou a cargo de Manoel Alves da Costa e teve algumas alterações designadas pela Câmara com o intuito de abarcar um novo item da lista de problemas urbanos que se tornava primordial: segurança. De acordo com o jornal Correio Catharinense de 09/02/1853, a Iluminação Pública passou a compor-se de "65 lampiões, colocados nas esquinas ou nos lugares, onde prestando mais claridade facilitão o trânzito do povo e da polícia". ${ }^{31}$ Dois anos depois o presidente da Província assinava

a contratação do Serviço de Iluminação a gaz com Vicente Nery por três annos pela quantia de 5:600\$000 reis annual, sendo os primeiros quatro meses feita com azeite. A illuminação a gaz é por sem duvida mais acceiada; não dão porem os lampiões atuaes tanta luz, como os antigos de azeite, e se mais clara se acha hoje a illuminação he isso devida a limpeza dos vidros, que se não embação como os antigos com o fumo do azeite. ${ }^{32}$

O mesmo processo de melhoramento se deu com a praia fronteira ao Mercado que, além de ponto de comércio, era o porto de entrada da cidade, como tal fazia-se necessário, ao menos, torná-lo transitável. Para tanto, quando o Mercado foi reconstruído em um ponto mais afastado da praça, em 1896, a vista da praia fronteira ficou aberta e a raia passou a receber menos despejos, isso aliado aos melhoramentos feitos no trapiche de desembarque do porto que havia sido construído em 1874 e de um primeiro aterro nessa área frontal, 'capacitaram' o local a ser área de recreio para famílias da cidade. ${ }^{33}$

Essas obras executadas eram apenas uma pequena parte da relação de obras apontadas como necessárias para a cidade no que se refere ao estado sanitário e asseio. O jornal Correio Catharinense listou esses problemas e os divulgou em seu $n^{\circ} 14$ de 16/02/1853, baseado no ofício de 24/02/1852 do presidente da Província. Entre as obras estavam melhoramentos nas fontes da Palhoça, da Carioca e do Campo do Manejo com o escoamento das águas que sobravam dessas fontes e se estagnavam em alguns locais da cidade; encanamento das águas do Rio Fonte Grande e terrenos lactantes em toda a sua extensão; encanamento por meio de valas das águas que nascem no fundo 
das chácaras e que fazem frente à Rua do Passeio; desaguamento dos charcos localizados em terrenos particulares do centro da cidade - nominados no ofício -; dessecamento por meio de aterro, em toda sua extensão da marinha, desde Santa Bárbara até a Rua da Toca e multiplicação dos depósitos de água. Ainda faziam parte da lista o cercamento de terrenos não ocupados por muros para evitar o acúmulo de lixo e imundices; mudança para local mais afastado da cidade do hospital militar de Santa Bárbara; remoção do cemitério público para o lado sul da cidade ou para leste; construção de uma cadeia ou remoção da atual, sendo indicado próximo ao Campo do Manejo como local ideal, além da construção de alguns pequenos cais para despejos das imundices, que ainda eram jogadas nas ruas pelas janelas de algumas casas. Esse ponto era recorrente, apesar de, ainda em meados dos XIX, quando de uma epidemia de cólera que assustou a cidade, a Câmara ter construído três trapiches de madeira para que os tigres fossem despejados o mais distante possível mar adentro. ${ }^{34}$

Sobre o cemitério, até 1841 o convencional era os sepultamentos no corpo das igrejas ou o emparedamento nessas por se tratar de edifício sagrado construído em solo que também tinha esse caráter, daí a importância de ter a última morada nesse local. Porém, nesse ano ocorreu uma epidemia que foi chamada de 'febre cerebral' e cuja causa foi atribuída aos miasmas provenientes dos corpos enterrados nas igrejas e que eram aspirados pela população. $\mathrm{O}$ presidente da Província proibiu, em junho daquele ano, os enterros de cadáveres no corpo das igrejas ou em catacumbas, sendo que os corpos deveriam ser sepultados no cemitério público, instalado no Morro do Vieira. ${ }^{35}$ A cadeia também era vista como um disseminador em potencial de odores e miasmas que poderiam prejudicar os moradores locais e provocar epidemias, ainda mais porque muitas de suas janelas haviam sido fechadas para aumentar a segurança e, conseqüentemente, impediu a renovação eficiente dos ares de seu interior. ${ }^{36}$

Esse argumento de transformar o centro da cidade em local 'freqüentável' por pessoas ditas 'de bem' foi critério para influenciar a mudança de local da construção do novo prédio da Alfândega que explodiu em 24 de abril de 1866. As discussões atrasaram o início das obras da nova Alfândega em oito anos. ${ }^{37}$ Esse ponto de entrada e saída de produtos na Ilha e de sua fiscalização era local de trabalho de escravos e de toda a sorte de 'homens brutos', portanto, era interessante que fossem afastados do centro e da praça para que, desta forma, tais locais pudessem ser melhorados.

Essa constante construção e reconstrução da cidade como 'urbes' e como 'civita', como espaço e como política, é um ponto importante das práticas sociais de Desterro, pois, de acordo com Omegna, isso se inscreve na própria idéia de cidade, que 
não seriam as casas, as cabanas, os armazéns. É um espaço para as casas, as famílias, mas é mais ainda, é a área para o ajuntamento civil, para os comícios populares, para os câmbios da riqueza, para as decisões dos órgãos do poder público, para os convívios humanos. A polis para a vida política. ${ }^{38}$

Quando nos referimos a essa cidade (urbes) e seus locais específicos, como praças e ruas, estamos analisando a construção da idéia de espaço público, que não é uma qualidade intrínseca do espaço, como já assinalado antes. ${ }^{39}$ Esse controle dos espaços era uma atuação que restringia os direitos tradicionais de presença e de uso para formar e limitar a sua apropriação privada, transformando-as, de acordo com a nova noção de espaço público urbano. ${ }^{40}$ Tal ordenação dos espaços públicos passa pela definição do que são e para quem são destinados, como

órgãos essenciais à vida urbana [que] são a rua, a praça, o templo, o mercado, o foro, o circo, o theatron (literalmente, 'o logar em que se olha... e se é olhado'), isto é, a cidade são os canais que levam o homem à presença dos outros homens, e os recintos para todas as formas de convivências que aplacam a angústia de ser só, a estreiteza de ser particular e curam a sensação da insuficiência da casa, do círculo doméstico e dão a oportunidade a que cada homem faça de sua vida uma tangente de outras vidas. ${ }^{41}$

Outra qualidade do espaço, segundo Simmel, "consiste em dividi-lo em partes para o aproveitamento prático, partes que se consideram como unidades e - tanto por causa como por efeito disso - estão rodeados de limites". ${ }^{42}$ Sempre concebemos o espaço que um grupo social ocupa, seja ele um bairro, um Passeio Público ou praça como uma unidade expressa e sustentada por tal grupo, é o grupo que faz o lugar e é feito por ele. Quando nos referimos aos motivos da iluminação da Praça de Desterro, estamos confirmando a idéia corrente da época que, ainda de acordo com Simmel, esse espaço, se freqüentado por 'pessoas de bem', tornar-se-ia bom e bem visto por todos, portanto, seria freqüentável por todos que não ferissem as novas normas de conduta, ou seja, esse novo local estava vetado para trabalhadores e escravos.

O princípio 'público' designa algo que é de todos ou ao menos que pode ser usufruído por todos. Quando se cerceia a freqüência de escravos ou, mais ainda, de trabalhadores do porto na Praça de Desterro ou a cerca-se com grades como ocorreu em fins do século XIX, se está separando a idéia de cidadãos, se está atribuindo valores a pessoas e, com isso, designando o que umas e outras 
podem fazer. Isso é uma clara forma de, no âmbito social, exercer um tipo de função policial. Essa criação de limites é,

comparado con la naturaleza, [...] arbitrario, aun en el caso de las islas; pues en principio, el mar puede ser también objeto de posesión. Precisamente, el no depender del espacio natural pone de relieve el poder formal de la cohesión social y la necesidad interna que satisface por la determinación precisa del límite físico, una vez puesto. Por esa razón, acaso sea mayor la conciencia de la delimitación, no frente a los llamados límites naturales (montañas, ríos, mares, desiertos), sino justamente frente a los límites meramente políticos, que no hacen sino trazar una línea geométrica entre los vecinos. ${ }^{43}$

Esses limites que Simmel classifica como "acontecimentos espirituais ou sociológicos", quando transformados em linhas do espaço, sua relação mútua adquire claridade. Isso pode ser algo negativo ou positivo, mas nunca deixa de ser rígido. Tal claridade, segurança e rigidez "no les son dadas cuando la coincidencia o separación de las fuerzas y derechos no se ha proyectado aún en forma sensible, y se halla, por tanto, por decirlo así, en estado naciente". ${ }^{44}$

Esses limites também podem ser observados através de normas, regras de conduta ou normatização do espaço urbano. Além da ordenação das ruas com nomes que designavam atividades e que, segundo Gilberto Freyre ${ }^{45}$, tinham um caráter sindicalista ou medievalista, indicando negócios como 'Rua dos Ourives' ou 'Rua da Quitanda' ou procedências como 'Rua dos Judeus' ou 'Rua dos Ciganos'. Ainda referindo-se a Desterro, podemos analisar a redefinição de usos ou hábitos locais ao observarmos as mudanças nas posturas municipais no que se refere aos despejos. A própria palavra postura que, de acordo com Murillo Marx, sempre foi usada, no âmbito das cidades como sinônimo de ordenação do espaço e das pessoas, defina horários para determinadas práticas.

Essas constantes separações e entrelaçamentos da cidade como espaço físico e da cidade como 'teatro' social observado em Desterro, em especial em sua área central que definia o centro da capital da Província de Santa Catarina, é um reflexo das construções do espaço público urbano que, no Brasil, e mais especificamente em Santa Catarina, ocorre no século XIX. Diferente das cidades européias ou mesmo do Rio de Janeiro, que já tinham conceitos definidos, e redefinidos corriqueiramente sobre espaços físicos e suas funções sociais no âmbito do urbano, Desterro se constrói como urbes no século XIX.

A antes rural e praticamente isolada cidade passa a ter um porto mais movimentado e, com isso, um comércio em crescimento. Exportações de 
café, amendoim, açúcar e, principalmente, farinha de mandioca para o Rio de Janeiro e Províncias do Prata traziam, além de dinheiro, informações e novos costumes. Surgiram sobrados na Rua Augusta (atual João Pinto), na Rua do Príncipe (atual Conselheiro Mafra) e na Praça Central. A Desterro do último quartel do século XIX tinha seu centro assobradado, sua praça arborizada e harmoniosa, convidativa para passeios. Outros espaços de lazer foram sendo construídos, como o Teatro Santa Isabel, a Biblioteca Pública, o Atheneo Provincial, além de cafés e confeitarias que eram pontos de encontros e conversas. Os limites urbanos de Desterro contavam, já em 1876, com oito igrejas, seis sobrados particulares e sete edifícios térreos também particulares, sete edifícios provinciais e municipais (um desses era o cemitério católico), sendo dois deles sobrados, dois hospitais, um cemitério evangélico, duas lojas maçônicas e 1.751 prédios urbanos, sendo desses 126 sobrados e 1.625 térreos. ${ }^{46}$ Na planta de Desterro apresentada anteriormente, o autor enumerou setenta ruas, becos, travessas e largos no perímetro urbano, além de oito chácaras, um engenho, uma fábrica de sabão e um estaleiro. ${ }^{47}$

Somando-se a isso havia os avanços industriais e mecânicos que levaram iluminação para as ruas além de um comércio que atraía pessoas, muitas delas senhoras de 'boa família' que passaram a andar pela cidade. Enfim, os espaços urbanos passaram a ser espaços de socialização. A vida saiu de dentro das casas e foi para a rua e para a praça. Uma grande 'rua de mão dupla', em que pessoas moldavam os espaços e eram moldadas por eles, os ressignificando e sendo por eles ressignificadas.

\section{CONSIDERAÇÕES FINAIS}

Este texto buscou analisar, sob a ótica da história ambiental, o surgimento de práticas e experiências vinculadas ao desenvolvimento de novas relações entre humanos e não humanos em um espaço tido como urbano. Não raro, e por muito tempo a 'sociedade' e a 'natureza' foram trabalhados como elementos opostos e separados, impedindo que se fizesse a ligação necessária entre meio ambiente e pessoas que muitas vezes direcionaram práticas e redefiniram a construção dos espaços urbanos, ideias de progresso e muitos hábitos sociais.

A natureza ou tudo que não é produto direto da ação humana também tem influência nas decisões tomadas, uma vez que o solo, o clima ou o fornecimento de água são alguns dos alicerces de uma sociedade e ela só se forma em locais onde esses itens são favoráveis ou, em contrário, quando existe tecnologia para adaptá-los. Essa também foi uma característica da formação da sociedade na Ilha de Santa Catarina. O local de instalação da vila e depois cidade de Nossa Senhora do Desterro era um ponto estratégico de defesa portuguesa ao sul do Brasil e essa condição geográfica privilegiada foi o primeiro passo para a 
criação de uma comunidade. Foram considerados também outros elementos como o melhor local da Ilha para a instalação da vila, qual seja o mais próximo do continente, com fácil abastecimento de água potável, de lenha e madeira, além de ser plano e aprazível, na medida do possível.

Diferente de algumas opiniões que indicavam o local como um paraíso, a Ilha também tinha características consideradas problemáticas para o 'florescimento' de uma cidade como os mangues próximos que, apesar das madeiras fáceis de serem derrubadas e utilizadas, também eram focos do que era considerado o grande mal do período: os miasmas causadores de doenças. Essa e outras características entendidas como negativas demandaram um longo processo de adaptação e transformação da natureza local com a adequação de muitas áreas para os padrões tidos como ideais ou minimamente aceitáveis para a sobrevivência e progresso de uma sociedade civilizada.

Ao considerarmos as limitações e influências ambientais impostas pela insularidade e pela natureza de modo geral, percebemos com mais clareza a relação mantida entre o homem e o meio natural nessa constante adaptação e readaptação, sendo essa a linha que procuramos seguir no desenvolvimento do trabalho. Penso que o entendimento dessas transformações ambientais locais como fazendo parte de um processo social e cultural, além de econômico e/ou político, amplia o entendimento da historia ilhoa. Certo é que tais transformações foram parte das causas e das conseqüências da colonização e dos ideais de progresso do período.

Observando novos ângulos de um mesmo prisma, procurou-se dimensionar melhor a natureza ilhoa e o processo de transformação dela durante o período estudado. Essas questões analisados separada e pontualmente, permitiram uma abordagem mais ampla da história da cidade de Nossa Senhora do Desterro no século XIX, seu crescimento às vezes desordenado e o próprio desenho urbano. O mapa de Desterro visto sob essa perspectiva, em que a natureza é personagem e não apenas cenário, ganha outros contornos, outros odores e sabores e, justamente por isso, pode-se chegar à conclusão que práticas culturais, meio ambiente e as pessoas que ali viveram, em suas constantes interações e transformações, são facetas do mesmo objeto.

\section{NOTAS}

EDUARDO, A. R. B.; FERREIRA, A. L. A. As Topografias Médicas no Brasil do início do século $X X$. Aportes históricos ao estudo da relação meio ambiente e sociedade (o caso de Natal-RN). In: FERREIRA, Angela; DANTAS, George. (Org.). Surge et Ambula. A construção de uma cidade moderna (Natal, 1980-1940). V. I. Natal: EDUFRN, 2006. p. I37-I 5 I.

2 VIGARELLO, Georges. O limpo e o sujo: uma história de higiene corporal. São Paulo: Martim Fontes, 1996. p. 121 . 
Meio ambiente e saúde pública: a urbanização de Nossa Senhora do Desterro no século XIX

3 Ibid., p. 134.

${ }^{4}$ SANTOS, Manuela Arruda dos. Cuidado com o tigre! Revista de História da Biblioteca Nacional. Edição 3 I, abr. 2008. Disponível em: < http://www.revistadehistoria.com.br > .

5 MOURA, Antonio Ribeiro. Manual do Edificante do proprietário e do inquilino ou novo tratado dos direitos e obrigações. Rio de Janeiro, I858. Acervo: Biblioteca Particular de Cândido Mendes de Almeida.

6 RAMOS, Átila. O Abastecimento de água de Florianópolis. Disponível em: < http://www.casan. com.br/comp_hist_saneamento.htm >. Acesso em: 18 out. 2005.

7 Segundo Cavalcanti e baseado nos levantamentos feitos pelos lançadores da décima urbana no Rio de Janeiro, o Imóvel rotulado como chácara possuía testada que ultrapassava a de um terreno urbano e, via de regra, além da 'casa da vivenda', possuía outros prédios para senzala, cocheira, estrebaria, telheiro, depósito e outras construções como curral, ou olaria, ou engenho de farinha, ou fabrica de anil. In: CAVALCANTI, Nireu. O Rio de Janeiro Setecentista: a vida e a construção da cidade da invasão francesa até a chegada da corte. Rio de Janeiro: Jorge Zahar, 2004. p. 264.

${ }^{8}$ CABRAL, O.R. Memória histórica, authentica, sincera, pictoresca e sentimental da Villa, depois cidade de Nossa Senhora do Desterro da ilha de Sancta Catharina, dos casos raros alcunhada: memória. V. I. Florianópolis: UFSC, 197I. p. 169.

9 VALLE, Severo Amorin. Falla do Presidente de Província dirigida à Assembléia Legislativa de Santa Catarina, $1^{\circ}$ de março de 1849. Disponível em: < http://brazil.crl.edu/bsd/bsd. 08/03/07>

${ }^{10}$ Código de Posturas da Câmara Municipal da Capital da Província de Santa Catarina. Nossa Senhora do Desterro, 10 de maio de 1845. Artigos 15 e 20, capítulo 2. p. 212-213.

" RIBEIRO DE ALMEIDA, João. Ensaio sobre a salubridade, estatística e pathologia da Ilha de Santa Catarina e em particular da cidade de Desterro. Desterro: Typ. JJ. Lopes, I864. p. 4I.

${ }^{12}$ Código de Posturas da Câmara Municipal da Capital da Província de Santa Catarina. Nossa Senhora do Desterro, 10 de maio de 1845. Artigos 54, capítulo 2. p. 14.

${ }^{13}$ CABRAL. O. R. Op. cit, p. 174.

${ }^{14}$ COUTINHO, João José. Falla do Presidente de Província dirigida à Assembléia Legislativa de Santa Catarina, $1^{\circ}$ de março de 1854. Disponível em: <http://brazil.crl.edu/bsd/bsd>. Acesso em: 08 mar. 2007.

${ }^{15}$ RIBEIRO DE ALMEIDA, João. Op. cit., p. 34.

${ }^{16}$ Ibid., p. 34.

17 Ibid., p. 38.

${ }^{18}$ Ibid., p. 39.

19 MELLO ALVIN, João de Souza. Relatório apresentado ao Sr. Presidente de Província pelo Sr. Capitão de engenheiros João de Souza Mello Alvin sobre as fontes públicas desta Capital. Jornal O Conciliador Catarinense. 17 nov. I849, p. 02, 03 e 04 - col: 01 . Acervo Biblioteca Nacional.

20 Ibid., p. 2, 3 e 4.

${ }^{21}$ RIBEIRO DE ALMEIDA, João. Op. cit., p. 4I.

22 Ibid., p. $4 \mid$ 
Meio ambiente e saúde pública: a urbanização de Nossa Senhora do Desterro no século XIX

${ }^{23}$ ALMEIDA, Luciana Cristina de. "Nossa Senhora do Despejo" O lixo e a imundície em Nossa Senhora do Desterro no fim do Império. (décadas de 1850, 1860 e 1870). Florianópolis, 2003. Monografia em História. Universidade do Estado de Santa Catarina, Florianópolis - UDESC. p. 69-70.

${ }^{24}$ RIBEIRO DE ALMEIDA, João. Op. cit., p. 7I.

25 Ibid., p. 74.

26 lbid., p. 75.

27 Ibid., p. 77.

${ }^{28}$ LOUZADA, Maria Alexandre. A rua a taberna e o salão: elementos para uma geografia histórica das sociabilidades lisboetas nos finais do Antigo Regime. In: VENTURA, Maria da Graça A. Mateus (coord) Os espaços de sociabilidade na Ibero-América (séc. XVI-XIX). Lisboa: Edições Colibri, 2004. p. 96.

29 SENNETT, Richard. Carne e Pedra: $\bigcirc$ corpo e a cidade na civilização ocidental. 3 ed. Rio de Janeiro/São Paulo: Ed. Record, 2003. p. 27I.

30 LOUZADA, Maria Alexandre. Op. cit., p. 96.

31 Iluminação Pública. Correio Catharinense - jornal commercial, noticioso e literário, Nossa Senhora do Desterro, 09 fev. I853, n 13, p. 01, colunas 2 e 3. Acervo BN.

32 Falla do Presidente de Província. O Conservador, Nossa Senhora do Desterro, 08 mai. I855, n. 321 , p. 03, coluna 03.

${ }^{33}$ CABRAL, O. R. Op. cit., v. I, p. 176- 177.

${ }^{34}$ Correio Catharinense - jornal commercial, noticioso e litterario, Desterro, 16 fev. I853, n. I4, p. 01, colunas I, 2 e 3. Acervo: BN.

35 ALMEIDA, L. C. Op. cit., p. 69-70.

36 Ibid., p. 70.

${ }^{37}$ CABRAL. O. R. Op. cit., p. 176- 177.

38 OMEGNA, Nelson. A cidade colonial. 2 ed. EBRESA, Brasília, 197I . p. 08.

39 LOUZADA, Maria Alexandre. Op. cit., p. 96.

40 lbid., p. 105.

${ }^{41}$ OMEGNA, Nelson. Op. cit., p. 80.

42 SIMMEL, Georg. Sociologia: Estúdios sobre lãs formas de socialización. V.II. Madri: Biblioteca de la Revista de Occidente, 1977. p. 649-650.

43 lbid., p. 650.

${ }^{44}$ Ibid., p. 654.

45 FREYRE, Gilberto. Casa grande e senzala, 26 ed. Rio de Janeiro: Record, 1989.

${ }^{46}$ TAUNAY, Alfredo D'Escragnolle. Op. cit.

47 lbid. 